\title{
USING STRAWBERRY (Fragaria ananas) VINE HAY IN RATIONS OF GROWING LAMBS.
}

Galal, H. M. F $^{1}$. ; M. A. El-Menniawy ${ }^{1}$; M. H. Abo El-Fadel ${ }^{1}$; A. A. Khir ${ }^{1}$ and Safaa N. Abdel-Azeam ${ }^{2}$.

${ }^{1}$ Utilization of By-products Department, Animal Production Research Institute, Agricultural Research Center Giza, Egypt.

${ }^{2}$ Sheep and Goats Department, Animal Production Research Institute, Agricultural Research Center, Giza, Egypt.

\section{ABSTRACT}

This study was conducted at Sids Experiment Station, Animal Production Research Institute, Agricultural Research Center, to evaluate the effect of inclusion strawberry vine (SBV) as an untraditional ingredient in lambs ration on their growth performance. Twelve lambs averaged $17 \pm 0.94 \mathrm{Kg}$ live body weight were divided into three similar groups according to their body weights (4 lambs in each) and were used in a comparative feeding trial. Control ration (D1) was formulated from $70 \%$ concentrate feed mixture (CFM) plus $30 \%$ rice straw (RS) on dry matter basis in order to cover $100 \%$ of NRC feeding standard. Tested rations (D2 and D3) were formulated so that 25 or $50 \%$ of the total CP of the control ration were supplied from strawberry vines hay, respectively. Digestion trials were conducted to determine the digestibility and feeding values of the experimental rations. Growth performance parameters were evaluated and samples of rumen liquor and blood were analyzed as well.

Results showed that concentration CP and NFE of strawberry vine hay were higher, while CF and ash were lower than those rice straw, while NFE of strawberry vine hay was similar to that of CFM. The OM digestibility of D2 was significantly higher than that of D1 (control) or D3. The digestibility coefficients of CP, EE and NFE of D2 were significantly higher than those of D1 and insignificantly higher than those of D3. Value of CF digestibility of D2 was significantly higher than that of D1 or D3. The TDN of D2 was significantly higher than that of D1 and D3, and the value of DCP of D2 was significantly higher than that of $\mathrm{D} 1$ and insignificantly than $\mathrm{D} 3$. Rumen $\mathrm{pH}$ value of lambs fed D3 was significantly higher than those of D1 and D2 at 3 and 6 hrs post feeding, while the differences between D1 and D2 were not significant. RUMINAL Ammonia- $\mathrm{N}$ and total VFA concentrations were not affected by dietary treatments. No significant differences were found among treatments in most measured blood serum constituents. Daily gain of D2 was significantly higher than that of D1 and D3, and D1 was significantly higher than D3. Feed conversion (DMI/gain) of D2 was significantly better than that of D3 and insignificantly better than that of D1. Total cost of D2 and D3 were significantly lower than D1 and the economical efficiency of D2 was higher than that of D1 and D3.

It could be concluded that $25 \%$ of $\mathrm{CP}$ of lambs ration consisting of concentrate feed mixture and rice straw could be replaced by strawberry vines hay protein, since it increases daily gain and improves the economical efficiency.

Keywords: Strawberry vines, lambs, growth, feed utilization, rumen and blood parameters.

\section{INTRODUCTION}

The annual feed requirements for animal wealth in Egypt are about 14 million tones of total digestible nutrients (TDN). The shortage of animal feeds was calculated to be approximately 3.1 million tons of TDN (Fayed et al., 2009). According to this problem, growing attention is focused on the use 
of crop by-products, agricultural residues, industrial by- products, wastes of fruits and vegetables for ruminant feeding which could be considered as a significant trend to alleviate the acute shortage of feedstuffs in Egypt and most developing countries, as well as diminishing the environmental pollution (Abou Selim and Bendary, 2005). Furthermore, such application certainly reduces the amounts of some feedstuffs that are annually imported for animal feeding.

In Egypt, about 25 million tons of agricultural by products are annually produced (Ministry of Agriculture and land Reclamation, 2008). Utilization of agricultural vines residues can partly alleviate the gab between animal nutritional requirements and available feedstuffs and thus it is so necessary to investigate.

In Egypt, animals are suffering from shortage of feeds especially during summer season during which they almost depend on grains, concentrate feed mixtures and crop by-products mainly wheat and rice straws. The rising costs of concentrate feeds (grains and proteins supplements in particular) have led to significant increases in animal feed cost in recent years (Omer et al, 2011). In perspective, including local agricultural by-products into ruminant diets could reduce the feed cost and in turn increase the economical efficiency of live stock production (Borhami and Yacout, 2001). Also, Saleh et al., (2003) reported that including some vegetables vine hays in lactating buffalo rations to replace berseem hay could reduce feed cost by $20 \%$ and improve economical efficiency by $27 \%$. Recently, strawberry was introduced as a new fruit crop for human consumption in Egypt and its annual production are steady increasing. Omer et al. (2011) and Galal et al. (2014), showed that the strawberry vines hay had higher NFE and DE and lower CP and CF than berseem (Egyptian clover). There is a limited literature on using strawberry residues in feeding ruminants, therefore there is an extreme need for more studies on using these residues in feeding farm animals. The aim of this study is to evaluate the nutritive and feeding values of strawberry vine hay and the possibility of inclusion this residue as a source of protein in lambs rations.

\section{MATERIALS AND METHODS}

This study was conducted at Sids Experimental Station (Beni Swief Governorate), Animal Production Research Institute, Agricultural Research Center, Ministry of Agriculture, Egypt. Twelve lambs with an average live body weight of $17 \pm 0.94 \mathrm{~kg}$ were used in a comparative feeding trial to study the potentiality of utilization of strawberry vines hay in lamb rations. Animals were divided into three similar groups of four replicates according to their LBW and rate of daily gain during a 21-d preliminary period, using a randomized complete block design. Animals were individually fed over the 120-d experimental period according to NRC recommended standard for sheep (1985) on the following dietary treatments: D1 (control ration) which consisted of $70 \%$ concentrate feed mixture CFM plus $30 \%$ rice straw (RS) to cover $100 \%$ of their requirements. Tested rations (D2 and D3) were formulated so that 25 and $50 \%$ of total CP of control ration were supplied 
from strawberry vines hay (SBV), respectively. Lambs were weighed at the beginning of the experiment, then fortnightly. Daily body gain was determined and feed conversion was calculated. Three digestibility trials were conducted simultaneously on 9 animals ( 3 in each group) at the last month of the feeding trial to evaluate the digestibility and feeding values of the experimental rations. The chemical composition of diets and feces were analyzed according to AOAC (1996).

Rumen fluid samples were taken from 9 lambs ( 3 in each group) using a stomach tube at 0,3 and 6 hours post feeding. The samples were filtered through three layers of cheesecloth. Ruminal $\mathrm{pH}$ was immediately measured by a digital $\mathrm{pH}$ meter. Rumen ammonia- $\mathrm{N}$ was determined according to Conway (1957) and total volatile fatty acids (VFA) were measured as described by Warner (1964).

Blood samples were taken from all lambs at the end of the experimental period from the jugular vein where they were directly collected into vacuum tubes and centrifuged at $4000 \mathrm{rpm}$ for $15 \mathrm{~min}$. Serum was separated into polypropylene tube and stored at $-20^{\circ} \mathrm{C}$ until analysis for total protein and albumin according to Weichelbaum (1946) and Doumas et.al. (1971), respectively. Globulin value was calculated by the difference between total protein and the corresponding value of albumin. Urea concentration was determined by the method of Henry and Davidsohn (1974). Gulutamic oxaloacetic transaminase (GOT) and glutamic pyruvic transaminase (GPT) were determined as described by Reitman and Frankel (1957). Creatinine was measured according the method described by Bartels, (1971). Total lipids and cholesterol were estimated according to the methods of Boutwell (1972) and Allain et.al. (1974), respectively. All date were statistically analyzed using the general linear models process of SAS (1998). Data of percentages were subjected to arc-sin transformation to approximate normal distribution before being analyzed and means were separated using Duncan's multiple range tests (Duncan ,1955).

For the comparison among means of the experimental diets when the main effects were significant.

The model used was:

where:

$$
Y \mathbf{i j}=\mu+T i+e i j
$$

$$
\begin{aligned}
& Y i j=\text { the observation of } i j \\
& \mu=\text { the overall mean } \\
& \mathrm{Ti}=\text { the effect of } \mathrm{i} \text { treatments }(1: 3) \\
& \mathrm{Eij}=\text { random error }
\end{aligned}
$$

\section{RESULTS AND DISCUSSION}

\section{Chemical composition:}

Chemical composition data in (Table 1) showed that CP and NFE contents were markedly higher while CF and ash contents were lower with SBV than those of RS. The contents of OM and NFE of SBV were similar to those of CFM, but there were differences in CP, EE, CF and ash contents between SBV and CFM. The chemical composition of strawberry vine agreed 
with that obtained by Omer et al. (2011) and Galal et al. (2014). On the other hand, contents of $\mathrm{CP}$ and CF of strawberry vine hay were lower, while the NFE\% was higher than those in legume forage hay as berseem hay (Omer et al., 2011, Hamed et al., 2013 and Galal et al. 2014), pea straw (Hamed et al., 2013) and peanut tops hay (Etman and Soliman, 1999). On comparison with some straws and stover, CP and NFE contents of strawberry vine hay was higher than those of bean straw, corn stalks and rice straw and CF had the opposite trend (Mehrez et al., 2001). The chemical composition of experimental rations were nearly similar in most nutrient contents. Presumably, these nutrient concentrations in the three experimental rations appeared to be closely suitable for growing lambs and agree with (NRC, 1985) for sheep requirements.

Table (1): Chemical composition of feed ingredients and experimental rations on DM basis.

\begin{tabular}{|l|c|c|c|c|c|c|c|}
\hline \multirow{2}{*}{\multicolumn{1}{|c|}{ Items }} & \multirow{2}{*}{ DM\% } & \multicolumn{7}{|c|}{ Chemical composition (\%) } \\
\cline { 3 - 8 } & & OM & CP & EE & CF & NFE & Ash \\
\hline Ingredients : & & & & & & & \\
CFM* $^{*}$ & 91.02 & 90.12 & 14.01 & 3.60 & 14.29 & 58.22 & 9.88 \\
RS & 89.18 & 86.75 & 3.21 & 2.40 & 38.95 & 42.19 & 13.25 \\
SBV & 85.02 & 88.48 & 9.10 & 2.35 & 17.93 & 59.10 & 11.52 \\
Experimental rations & & & & & & & \\
D1 & & & & & & & \\
D2 & 90.44 & 89.53 & 10.85 & 3.17 & 21.86 & 53.65 & 10.47 \\
D3 & 88.93 & 88.57 & 10.60 & 3.06 & 19.99 & 54.92 & 10.43 \\
& 87.41 & 88.85 & 10.45 & 2.79 & 18.40 & 57.21 & 11.15 \\
\hline
\end{tabular}

* CFM consisted of $35 \%$ decorticated cotton seed cake , $25 \%$ corn grain, $30 \%$ wheat bran, $5 \%$ molasses, $2 \%$ limestone, $1.5 \%$ salt and $1.5 \%$ mineral and vitamin mixture.

Digestion coefficients and feeding values:

Digestion coefficients as shown in Table 2 showed that no significant differences among treatments regarding the digestibility of DM while the OM digestibility of D2 was significantly higher than that of D1(control) or D3, which was significantly higher than the value of $\mathrm{D} 1$. The digestibility of $\mathrm{CP}$, EE and NFE of D2 was significantly higher than those of D1 and insignificantly higher than those of D3. The CF digestibility of D2 was significantly higher than that of D1 or D3 while, the differences between D1 and D3 were not significant as shown in Table 2. The digestion coefficients of D2 and D3 (SBV - rations) were nearly similar to those of rations which contained concentrate feed mixture and peanut tops hay using sheep as reported by Etman and Solmian (1999) and higher than those (except CF digestibility) of rations contained concentrate feed mixture with different crop by-products with sheep (Mehrez et al., 2001).

The feeding values as TDN and DCP are presented in Table 2. The TDN of D2 was significantly higher than D1 (control) and D3, but the difference between D1 and D3 was significant, and DCP of D2 was significantly higher than that of D1 and insignificantly than that of D3. These results were somewhat lower than those obtained by Etman and Soliman (1999) who found that TDN values of CFM + peanut tops hay ration ranged from 70.3 to $75.1 \%$ and DCP ranged from 8.4 to $9.5 \%$. On the other hand, the 
TDN and DCP values of the present experiment were higher than those obtained by Mehrez et al. (2001) who used different roughages to concentrate ratios in ruminant rations.

Table (2): Digestibility coefficients and feeding values of the experimental rations.

\begin{tabular}{|l|c|c|c|c|}
\hline \multirow{2}{*}{ Items } & \multicolumn{3}{|c|}{ Experimental rations } & \multirow{2}{*}{ S.E. \pm} \\
\cline { 2 - 4 } & D1 & D2 & D3 & \\
Digestibility (\%) & & & & \\
DM & 67.53 & 65.62 & 66.42 & 1.41 \\
OM & $66.40^{\mathrm{c}}$ & $74.32^{\mathrm{a}}$ & $70.00^{\mathrm{b}}$ & 1.08 \\
CP & $66.16^{\mathrm{b}}$ & $73.02^{\mathrm{a}}$ & $69.90^{\mathrm{ab}}$ & 1.44 \\
EE & $60.21^{\mathrm{b}}$ & $66.14^{\mathrm{a}}$ & $61.91^{\mathrm{ab}}$ & 1.57 \\
CF & $54.22^{\mathrm{b}}$ & $60.09^{\mathrm{a}}$ & $54.67^{\mathrm{b}}$ & 1.24 \\
NFE & $71.80^{\mathrm{b}}$ & $80.19^{\mathrm{a}}$ & $75.35^{\mathrm{ab}}$ & 2.05 \\
Feeding values (DM,\%) & & & & \\
TDN & $61.84^{\mathrm{b}}$ & $68.35^{\mathrm{a}}$ & $64.42^{\mathrm{b}}$ & 0.99 \\
DCP & $7.18^{\mathrm{b}}$ & $7.74^{\mathrm{a}}$ & $7.30^{\mathrm{ab}}$ & 0.16 \\
\hline
\end{tabular}

a, $b$ and $c$ Means in the same row with different superscripts are significantly $(P<0.5)$ different.

\section{Rumen liquor parameters:}

The $\mathrm{pH}$ values of lambs fed D3 were significantly higher than those of D1 and D2 at 3 and 6 hrs post feeding, while the differences between D1 and D2 were not significant as shown in Table 3. The increases in $\mathrm{pH}$ values in D3 may be logically due to the marked low level of CFM in this ration that caused a decrease in TVFA and in turn raised the $\mathrm{pH}$ value. The $\mathrm{pH}$ values lie within the normal ranges of normally functioning rumen (5.5 to 7.3) as recorded by Hungate (1966), and agreed with those of El-Emam et al. (2014), Mohamed and Ibrahem (2003) and Mehrez et al. (2001) who investigated different formulas with different ingredients in ruminants rations which extremely affect ruminal fermentative end products. Ammonia- $\mathrm{N}$ and total VFA, were not significantly altered by treatments, but the highest value occurred with D2 at 6 hrs sampling time. These values of ammonia- $\mathrm{N}$ and TVFA's slightly changed due to the similarity of CP and NFE contents of experimental rations as shown in Table (1). However, the roughage: concentrate ratio (energy levels) of a ration could significantly affect the rumen function and its fermentative products (Mostafa et al., 2004). Moreover, Hungate, (1966) demonstrated that rumen microorganisms can utilize more $\mathrm{NH}_{3}-\mathrm{N}$ when more energy sources are fermented. Generally, Van Soest et al., (1991) revealed that the variation in TVFA's concentrations in rumen matched with the buffering capacity of feedstuffs (physically and chemically) which derived in part from the physical effects that they elicit in the rumen and on rumination rate. Ammonia- $\mathrm{N}$ concentration in this study was higher than those obtained by El-Emam et al. (2014) and Mehrez et al. (2001). 
Table (3): Rumen liquor parameters of lambs fed the experimental rations.

\begin{tabular}{|l|c|c|c|c|c|}
\hline \multirow{2}{*}{ Items } & \multirow{2}{*}{ Sampling time } & \multicolumn{2}{c|}{ Experimental rations } & \multirow{2}{*}{ SE \pm} \\
\cline { 3 - 5 } & & D1 & D2 & D3 & \\
\hline \multirow{2}{*}{$\mathrm{pH}$} & 0 & 6.80 & 7.03 & 7.05 & 0.08 \\
& 3 & $6.00^{\mathrm{b}}$ & $6.26^{\mathrm{b}}$ & $6.58^{\mathrm{a}}$ & 0.10 \\
\hline \multirow{2}{*}{ Ammonia-N } & 6 & $6.27^{\mathrm{b}}$ & $6.48^{\mathrm{b}}$ & $6.75^{\mathrm{a}}$ & 0.08 \\
\hline (mg/100ml) & 0 & 13.12 & 16.28 & 15.62 & 1.75 \\
& 3 & 45.00 & 42.93 & 50.40 & 5.56 \\
Total VFA's & 6 & 20.21 & 25.62 & 22.15 & 3.49 \\
\hline (meq/100 ml) & 0 & $7.95^{\mathrm{b}}$ & $8.66^{\mathrm{a}}$ & $8.10^{\mathrm{ab}}$ & 0.18 \\
& 3 & 15.53 & 14.61 & 13.70 & 1.56 \\
\hline
\end{tabular}

${ }^{a \text { and }}$ Means in the same row with different superscripts are significantly $(P<0.5)$ differ.

\section{Blood serum constituents:}

No significant differences were observed among treatments in blood serum constituents as total protein, globulin, urea, GOT, GPT, creatinine, total lipids and cholesterol, while albumin in D2 was significantly higher than that of D1 (control) and insignificantly higher than that of D3 as shown in Table 4. The obtained values of all blood constituents are within the normal range and agreed with those obtained by El-Emam et al. (2014) and Mohamed and Ibrahem (2003) for healthy growing lambs. Also, comparable results were obtained by Saleh et al., (2003) who found no significant differences in all blood constituents when they feed buffaloes on rations containing different levels of watermelon vine.

Table (4): Blood serum constituents of lambs fed the experimental rations.

\begin{tabular}{|ll|c|c|c|c|}
\hline \multirow{2}{*}{} & \multirow{2}{*}{ Items } & \multicolumn{3}{|c|}{ Experimental rations } & \multirow{2}{*}{ SE \pm} \\
\cline { 3 - 5 } & & $\mathbf{D 1}$ & $\mathbf{D 2}$ & $\mathbf{D 3}$ & \\
\hline Total protein & $(\mathrm{g} / \mathrm{di})$ & 7.07 & 7.56 & 7.32 & 0.15 \\
Albumin & $(\mathrm{g} / \mathrm{di})$ & $3.96^{\mathrm{b}}$ & $4.32^{\mathrm{a}}$ & $4.12^{\mathrm{ab}}$ & 0.10 \\
Globulin & $(\mathrm{g} / \mathrm{di})$ & 3.11 & 3.24 & 3.20 & 0.06 \\
Urea & $(\mathrm{mg} / \mathrm{di})$ & 48.58 & 40.16 & 43.15 & 3.27 \\
Got & $(\mathrm{u} / \mathrm{i})$ & 60.66 & 57.55 & 55.19 & 4.51 \\
GPT & $(\mathrm{u} / \mathrm{i})$ & 16.73 & 15.86 & 14.93 & 1.26 \\
Creatinine & $(\mathrm{mg} / \mathrm{di})$ & 1.32 & 1.23 & 1.26 & 0.04 \\
Total lipids & $(\mathrm{g} / \mathrm{di})$ & 2.86 & 2.53 & 2.67 & 0.14 \\
Cholesterol & $(\mathrm{mg} / \mathrm{di})$ & 66.84 & 64.12 & 65.68 & 4.90 \\
\hline
\end{tabular}

and ${ }^{2}$ Means in the same row with different superscripts are significantly $(P<0.5)$ differ.

\section{Feed intake:}

The differences of DM intake among treatments were not significant, while the TDN intake of D2 was significantly higher than those of D1 (control) and D3. On the other side, the DCP intake of D2 was significantly higher than D3 and insignificantly higher than D1 (control) as shown in Table 5. The increases in feed values intake (TDN, DCP) of D2 may be due to the improvement in digestibility of $\mathrm{OM}$ and other nutrients and consequently the feeding values as TDN and DCP.

\section{Growth performance:}

The average daily gain of D2 was significantly higher than that of D1 (control) and D3, and also the daily gain of control group was significantly 
higher than that of D3 as shown in Table 5. The improvement in daily gain of lambs fed D2 might be attributed to the more synergistic interactions amongst the ingredients of this ration that also has a more suitable portion of concentrates $(52.5 \%$ of DM) in relation to the other tested ration D3 that have only $35 \%$ of concentrates. Consequently, these metabolic and physiological responses could effectively improve the digestibility and the productive performance of growing lambs. In supporting to this explanation, Huhtanen (1991) concluded that the utilization of dietary energy depends not only the profile of nutrients made available from a particular feed but also from nutrient made available from other combined feeds. The author added that the associative effects of feeds (a well balancing ration) on the efficiency of energy utilization and animal production should be considered as one of the most important factors that should be taken into consideration when formulating ruminant rations. The daily gain of lambs fed CFM plus strawberry vine hay in this study was higher than those fed CFM plus peanut tops hay as reported by Etman and Solmian (1999) and lambs fed CFM plus bean straw, corn stalks or rice straw as reported by El-Ayek et al. (2001). The feed conversion as $\mathrm{kg}$ DM intake per $\mathrm{kg}$ live body weight of D2 was significantly lower than D3 and insignificantly lower than D1(control), and the differences of feed conversion as $\mathrm{kg}$ TDN or DCP per kg live body weight among the three treatments were not significant as shown in Table 5. So, the ration of low level of SBV had the best feed conversion ratio among the experimental treatments. The present results are in harmony with those obtained by Mostafa et al., (1993) and EL-Says et al. (1997) who found that feed conversion increased with increasing the level of concentrate mixture in the rations of cattle.

Table (5): Growth performance and feed conversion of lambs fed the experimental rations containing different levels of strawberry vine hay ( SBV).

\begin{tabular}{|c|c|c|c|c|}
\hline \multirow{2}{*}{ Items } & \multicolumn{3}{|c|}{ Experimental rations } & \multirow{2}{*}{ SE \pm} \\
\hline & D1 & D2 & D3 & \\
\hline Initial LBW & 17 & 17 & 17 & 0.94 \\
\hline Final LBW & $36.920^{\mathrm{ab}}$ & $39.320^{a}$ & $34.400^{b}$ & 0.99 \\
\hline Total gain & $19.920^{b}$ & $22.320^{a}$ & $17.400^{\mathrm{C}}$ & 0.44 \\
\hline Daily gain & $166^{\mathrm{b}}$ & $186^{a}$ & $145^{\mathrm{c}}$ & 3.65 \\
\hline Average LBW & 25.44 & 26.42 & 24.12 & 1.01 \\
\hline Daily DM intake per head $(\mathrm{g})$ & & & & \\
\hline Concentrate feed mixture (CFM) & 786 & 624 & 380 & - \\
\hline Rice straw $\quad$ (RS) & 359 & 217 & 75 & - \\
\hline Strawberry vine hay & - & 347 & 630 & - \\
\hline Total DM intake & 1145 & 1188 & 1085 & 45.25 \\
\hline TDN intake & $708^{\mathrm{b}}$ & $812^{\mathrm{a}}$ & $699^{\mathrm{b}}$ & 28.96 \\
\hline DCP intake & $82.21^{\mathrm{ab}}$ & $91.95^{\mathrm{a}}$ & $79.20^{b}$ & 3.31 \\
\hline $\begin{array}{l}\text { Feed conversion : } \\
\mathrm{Kg} \text { DMl/kg gain }\end{array}$ & $6.90^{\mathrm{b}}$ & $6.39^{b}$ & $7.48^{\mathrm{a}}$ & 0.31 \\
\hline $\mathrm{Kg}$ TDNI/kg gain & 4.27 & 4.37 & 4.82 & 0.20 \\
\hline $\mathrm{Kg}$ DCPI / kg gain & 0.495 & 0.494 & 0.546 & 0.023 \\
\hline
\end{tabular}

a, band $c$ Means in the same row with different superscripts are significantly $(P<0.5)$ different. 


\section{Economical efficiency:}

Total price of D2 and D3 were markedly lower than that of D1 as shown in Table 6 , due to the high price of concentrate feed mixture compared with strawberry vine hay. Also, the cost of each $\mathrm{kg}$ gain of D2 was significantly lower than that of D1 (control) and insignificantly lower than that of D3. Therefore, the D2 treatment had the highest return and economical efficiency due to its highest daily body gain and the lowest feed cost. These results are in agreement with those obtained by Saleh et al. (2003) who indicated that inclusion of some vegetable vines hay in lactating buffaloe rations to replace berseem hay could reduce feed cost by $20 \%$ and improve economical efficiency by $27 \%$. Generally, including local agricultural byproducts into ruminants diets could markedly reduce the feed cost and in turn increasing the economical efficiency of live stock production (Borhami and Yacout, 2001).

Table (6) : Feed cost and economical efficiency of feeding growing lambs on the experimental rations.

\begin{tabular}{|c|c|c|c|c|}
\hline \multirow{2}{*}{ Items } & \multicolumn{3}{|c|}{ Experimental rations } & \multirow{2}{*}{ SE \pm} \\
\hline & D1 & D2 & D3 & \\
\hline $\begin{array}{l}\text { Daily gain }(g / h) \\
\text { Daily feed cost }\left(L^{*} / h\right)\end{array}$ & 166 & 186 & 145 & - \\
\hline CFM (LE) & 2.155 & 1.710 & 1.043 & - \\
\hline $\mathrm{RS}$ (LE) & 0.160 & 0.096 & 0.033 & - \\
\hline SBV (LE) & - & 0.367 & 0.667 & - \\
\hline Total cost of feed (LE/h/d) & 2.315 & 2.173 & 1.743 & 0.09 \\
\hline Cost of kg gain (LE) & $13.95^{\mathrm{a}}$ & $11.68^{b}$ & $12.02^{b}$ & 0.52 \\
\hline Cost of $\mathrm{kg}$ as $\%$ of the control & $100^{\mathrm{a}}$ & $83.73^{b}$ & $86.17^{\mathrm{b}}$ & 2.49 \\
\hline Price of weight gain $(\mathrm{LE})^{* *} / \mathrm{h} / \mathrm{d}$ & 4.98 & 5.58 & 4.35 & - \\
\hline Economical efficiency & 2.15 & 2.57 & 2.50 & - \\
\hline
\end{tabular}

$\begin{array}{lll} & 2.5 & 2.50 \\ \end{array}$ *Based on prices of year 2014 which were 2500, 400and 900 LE / ton for CFM ,RS and SBV as fed, respectively.

${ }^{* *}$ The price of live body weight were 30 LE per $\mathrm{kg}$.

\section{CONCLUSION}

It could be concluded that $25 \%$ of $\mathrm{CP}$ of lambs ration consisting of CFM and RS could be substituted from strawberry vines hay CP since this improved digestion coefficients and nutritive values, increased total body weight gain and daily gain and improved the economical efficiency without adverse effects on health of growing lambs.

\section{REFERENCES}

A O A C (1996). Official Methods of Analysis, Association of Official Analytical Chemists.16th edition. Arling ton ,PA.,USA.

Abou Selim , I .A. and M. M. Bendary (2005) . Fedstuff resources in Egypt, Sources and maximization of its utilization. Animal Production Research Institue, Second Conference \& Regional Symposium on Bufffalo Production , 27-29 September, 2005, Sakha, Kafr El- Sheikh , Egypt . 
Allain, C.C., L.S. Poon. C.S.Char,W. Richmend and P. C. Fu (1974). Enzymatic determination of total serum cholestrol. Chem.,20:470.

Bartels, H.(1971). A colorimetric method for creatinine estimation. J.Clin. Chem. Acta .,32: 81.

Bautwell , J.H.M.(1972). Total lipid reagent set (colorimertric method) cai .Tex. Diagnostics, Inc.Chino CA 91710U.S.A.

Borhami, B.E.A. and M.H.M. Yacout (2001). Is the animal protein essential for better utilization of plant protein in ruminants? Egyptian J. Nutr. and Feeds (Special Issue) $4: 25$.

Conway, E. J. (1957). Microdiffusion analysis and Volumetric Error, Rev. Ed. Lockwood, London.

Doumas ,B ;W.Wabson and H.Biggs (1971). Albumin standards and measurement of serum with bromocreso green. Clin.C hem. Acta,30:87.

Duncan ,D.B.(1955). Multiple ranges and multiple F.Test, Biometrics, 11:1.

El-Ayek, M. Y., E.S. Soliman, A. Z. , Mehrez, E. A. El-Ayouty and M. E. ElKholany (2001). Influence of type of roughage on animal performance and carcass traits of growing lambs. Egyptian J. of Nutrition and Feeds, 4 (Special Issue): 209-220.

El-Emam, G. I. , Y.H. Hafez, H.R. Behery, E.I. Khalifa, E. I. Shehata and M. E. Ahmed (2014). Growth performance, some rumen and blood parameters of growing rahmani lambs fed rations containing triticale or berseem silage and their mixture. Egyptian J. Sheep \& Goat Sci., 9 (1): $67-76$.

El-Sayes, M.F., Mostafa, H.R.M. and Hathout, M.K. (1997). Nutritional and economical efficiency for using the maize silage in fattening buffalo calves locally. $5^{\text {th }}$ world buffalo congress, Caserta, Italy, October, 1316.

Etman, K. E. I. and E. S. Soliman (1999). Effect of feeding peanut (Arachis Hypogaea L.) tops with different levels of concentrates on performance of growing lambs. Egyptian J. of Nutrition and Feeds, 2 (Special Issue): 223-231.

Fayed, Afaf M.; M.A.El- Ashry and Hind A.Aziz (2009). Effect of feeding olive tree pruning by-products on sheep performance in Sinai . World J.Agric. Sci. ; 5(4):436 - 445.

Galal, H.M.F.; M.A.El Menniawy; M.H. Abo-Fadel; A.A. Khir and Safaa N.Abdel -Azeam(2014). Some nutritional studies on using strawberry (Fragaria $\times$ Ananas) vine as hay in rabbit ration.J.Animal and Poultry Prod. , Mansoura Univ., Vol. 5 (12) :635-647.

Hamed A.A. Omer and Azza M.M. Badr,(2013). Growth performance of New Zeland white rabbits fed diets containing different level of pea straw. Live Science Journal 10(2):1815-1822.

Henry , J.B. and T. S. Davidsohn (1974). Stanbio nzimatico urea nitrogeno (BUN)procedimiento No.1050. Clinical Diagnosis and measurement by Laboratory Methods. 16th ed. W.B. Saunders and Co.Philadelphia PA .P260.

Huhtanen, P. (1991). Associative effects of feeds in ruminants. Norwegian J. of Agric. Sci. Suppl. No. 5:37-57. 
Hungate, R. E. (1966). The Rumen and its Microbes. Acad. Press, NY.

Kearl , L.C. (1982). Nutrients requirements in developing countries. Utah Agric . Exp.Stat., Utah State Univ .logan , USA.

Mehrez, A. Z., E. M. Soliman, M. Y. El-Ayek, E. A. El-Ayouty and M. E. ElKholany (2001). Influence of roughage to concentrate ratio and type of roughage on digestibility, some rumen parameters and fiber fractions degradability of tested rations with ruminants. Egyptian J. of Nutrition and Feeds, 4 (Special Issue): 193-207.

Ministry of Agriculture and land Reclamation Report (2008). Agriculture economics. Bull, Center Dept. Agric ., Economic, Cairo, Egypt.

Mohamed, A. H. and K. Ibrahem (2003). Incorberation aromatic plants byproducts in ruminant diet 1- Effect of using aromatic plants byproducts on growing lambs performance. Egyptian J. of Nutrition and Feeds, 6 (Special Issue): 1209-1217.

Mostafa, M.R.M., A.S. Shalaby, A.M. Abd El - Gawad, A.M.A. Mohi - Eldin and E.S. Khalil (2004). Infulence of varying levels of dietary energy and feed intake on fattening performance of Friesian calves using TMR Feeding System. J. Agric. Sci, Mansoura univ. 29(9): 48874901.

Mostafa, M.R.M., EL. Kholy, S., Ghanem, H.M. and Abd El Malik, W.A. (1993). Productive performance of Friesian calver fed onad - libitum sor, hum hybrid forage (Pioneer 988) with or without concentrate supplementation. J. Agric. Sci; Mansoura Univ. 18(3): 682-692.

NRC (1985). Nutritional requirements of domestic animals. Nutrient requirements of sheep. National Research Council, Washington.

Omer ,H.A.A., FAF. Ali and Sh. AM. (2011). Strawberry By-Products as a partial replacement of clover hay in rabbit diets. American-Eurasian J. Agric. Environ. Sci., 11(6):815-823.

Reitman, S. and S. Frankel (1957). Calorimetric determination of GOT and GPT activity .American Journal Clinical Pathology,28:56.

Saleh, M.S., A.M. Metwally, M.I. Bassiouni and M.A.Elshora (2003). Utilization of watermelon vine in feeding ruminants. It. Effect of replacing berseem hay by watermelon vine hay in feeding lactating buffaloes. Egyptian J. Nutr. and Feeds, 6 (special issue): 617-626.

SAS,( 1998). SAS Procedure Guide. Version 6.12 Ed."SAS Institute Inc. Cary,NC.U.S.A.

Van soest, P.J., Robertson, J.B. and Lowis, B.A. (1991). Methods for dietary fiber, neutral detergent fiber and non - starch polysaccharides in relation to animal nutrition. J. Dairy Sci. 74: 3584.

Warner, A.C.J. (1964). Production of volatile fatty acids in the rumen. Methods of measurements. Nutr. Abstr. \& Rev. B 34: 339.

Weichselbaum , T.E.(1946). Quantitative colorimetric determination of total protein in serum. American Clinical Pathology; 7:40. 


\section{استخدام دريس عرش الفراولة فى علائق الحملان النامية

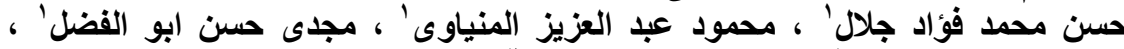

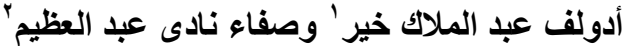

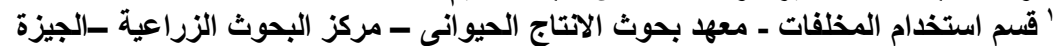

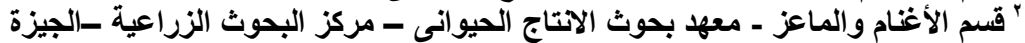

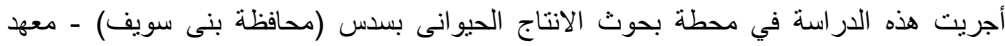

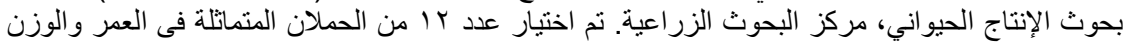

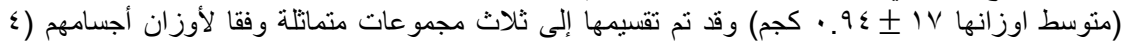

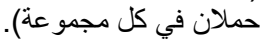
المجموعة الاولى D1 (الكنترول) التى غذيت على مخلوط العلف المركز وفش الأرز لتغطبة

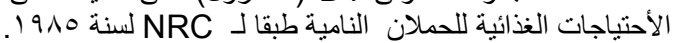

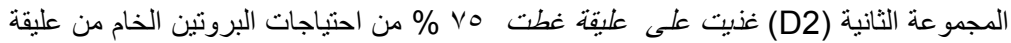
الكنترول + الك \% من عروش الفراولة الجافة.

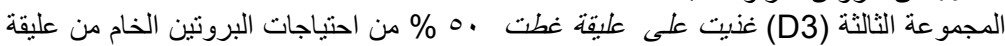

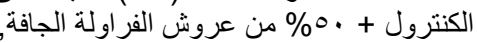

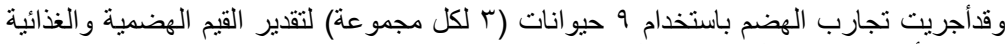

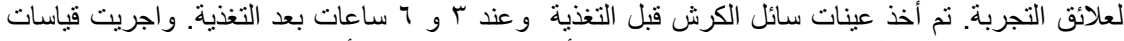

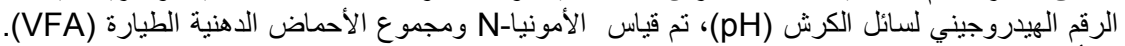

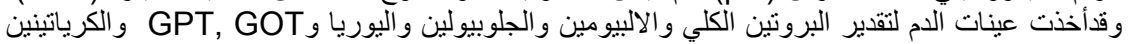

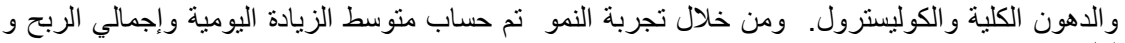

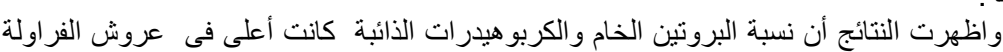

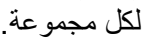

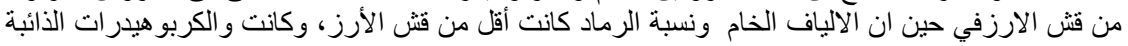

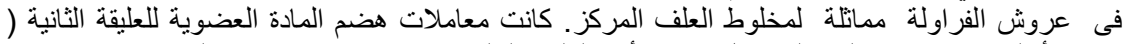

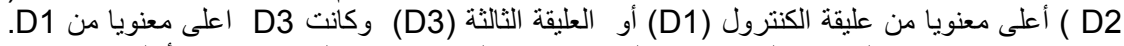

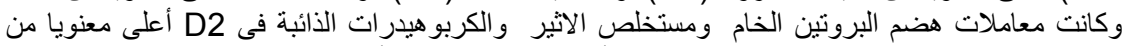

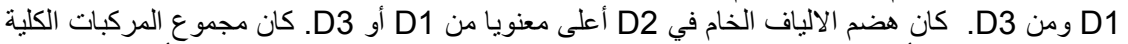

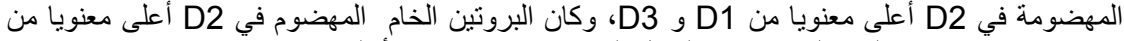

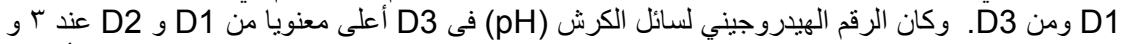

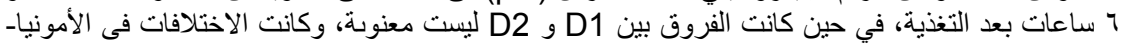

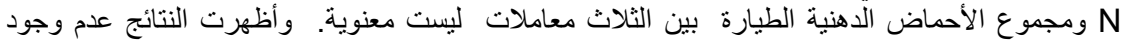

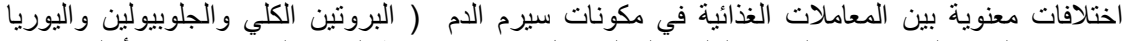

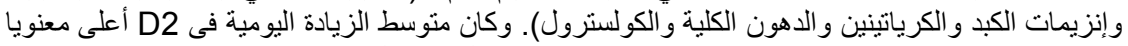

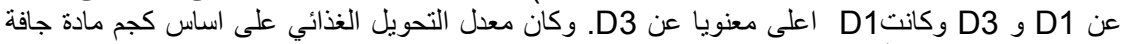

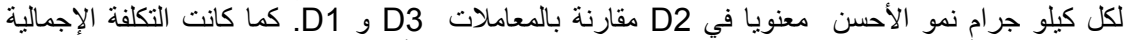

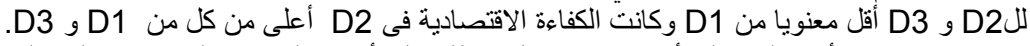

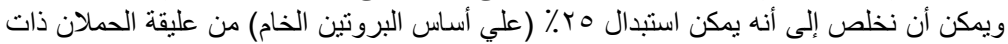

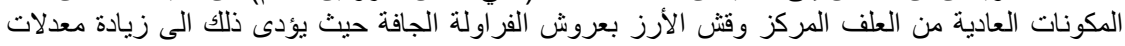
النمو للحملان وتحسين الكفاءة الغذائية والاقتصادية ولأرز ومن ثم زيادة الربح معنويا. 